\title{
ORIGINAL ARTICLE Prevalence of depressive and anxiety symptoms in medical students in the city of Santos
}

\author{
Prevalência de sintomas depressivos e ansiosos em \\ alunos de medicina na cidade de Santos \\ Rosana Denobile Serra', Sandra Lopes Mattos e Dinato', Marcos Montani Caseiro
}

\begin{abstract}
Objective: Ascertain the prevalence of depressive and anxiety symptoms in medical students, considering data in the literature that indicate higher vulnerability to emotional disorders in this population. Methods: A descriptive cross-sectional study with a sample of 657 (98\%) students. The instruments used were: questionnaire of socioeconomic-demographic characteristics, Beck Depression Inventory and Beck Anxiety Inventory. Results: Predominance of the female gender (61\%), aged between 17 and 30 years (98\%), Catholic religion (64.2\%) from the city of São Paulo (40.7\%) and other cities in the state (35.7\%); 30\% presented depressive symptoms and $21 \%$ anxiety symptoms. Female students had higher scores both for depression (34.8\%) and for anxiety (26.8\%). As regards the course year, the highest rates were found in the $5^{\text {th }}$ year (40.7\%) for depression and in the $2^{\text {nd }}$ year for anxiety (28.8\%).
\end{abstract}

Conclusion: The data obtained in this study (30\%) agreed with the literature regarding the prevalence of depressive symptoms in medical students, but this index was higher compared to the population in general (15.1\% to 16.8\%), and related to people in São Paulo city (18.5\%). Concerning anxiety the rates found were slightly lower than those in specific literature but higher than those in literature for the population in general (8\% to 18\%) and in city São Paulo

\section{Keywords}

Medical students, depression, anxiety. (16.8\%). These indices indicate that the school of medicine may play a role as a predisposing and/or triggering factor in some students. The results suggest that more attention should be directed to $5^{\text {th }}$ year students, who are beginning the internship period.

\section{RESUMO}

Objetivo: Verificar a prevalência de sintomas depressivos e ansiosos em acadêmicos de Medicina, considerando-se dados da literatura que apontam maior vulnerabilidade para distúrbios emocionais nessa população. Métodos: Estudo transversal descritivo com amostra de 657 (98\%) alunos, realizado na cidade de Santos, região do litoral paulista. Instrumentos utilizados: questionário de características socioeconômico-demográficas, Inventário para Depressão de Beck e Inventário de Ansiedade de Beck. Resultados: Predominância do gênero feminino (61\%), faixa etária entre 17 e 30 anos (98\%), religião católica (64,2\%), procedente da cidade de São Paulo (40,7\%) e de outras cidades do interior do estado (35,7\%); 30\% apresentaram sintomas depressivos e $21 \%$, sintomas ansiosos. O gênero feminino obteve escores mais elevados tanto para depressão (34,8\%) quanto para ansiedade (26,8\%). Em relação ao ano

1 Centro Universitário Lusíada (Unilus).
Received in

$7 / 6 / 2015$ 


\section{Palavras-chave}

Acadêmicos de Medicina, depressão, ansiedade. cursado, índices mais elevados para depressão foram constatados no $5^{\circ}$ ano $(40,7 \%)$ e para ansiedade no $2^{\circ}$ ano (28,8\%). Conclusão: Os dados obtidos neste estudo (30\%) foram concordantes quanto à prevalência de sintomas depressivos encontrados na literatura referentes a estudantes de Medicina e mais elevados em relação à população em geral (15,1\% a 16,8\%) e na cidade de São Paulo (18,5\%). Quanto à ansiedade, foram verificados índices ligeiramente inferiores aos da literatura específica e superiores aos da literatura na população em geral (8\% a 18\%) e na cidade de São Paulo (16,8\%). Tais índices indicam que a escola médica pode atuar como fator predisponente ou desencadeante em alguns alunos. Resultados sugerem maior atenção para com os alunos do $5^{\circ}$ ano, período referente ao início do internato.

\section{INTRODUCTION}

Studies indicate that the course of Medicine is a period of significant anguish for students of this field and that the prevalence of depressive and anxiety symptoms is higher among them than in the general population ${ }^{1-3}$.

In several parts of the world, such as the Middle East, Europe, USA and South America research is carried out on this topic ${ }^{2,4}$. In Brazil, reports on mental health of these students are present in schools of medicine in almost every state in the country ${ }^{3,5-11}$. Such studies reflect concern about the physical and psychological well-being of students enrolled in the course of Medicine ${ }^{1,35-11}$. It should be asked what happens with this population, which is so intellectually capable as to achieve success in very competitive entrance exams to schools of Medicine, but somehow are more vulnerable to stress and, consequently, to the onset of psychological disorders ${ }^{10,11}$.

Stressful factors inherent to the academic process are pointed out as possible causes of the origin of emotional problems $1,3,5,7,9,10$. Emotional intelligence, i.e., "the ability to identify our feelings and the others; to be motivated and to manage well our emotions inside ourselves and our relationships"12, linked to personality traits which will play an important role in facing these situations in the under graduate period. Investigation of this subject was intensified when it was found that some students became vulnerable to the onset of affective disorders during their college years, the most frequent alterations being of a depressive and anxious nature ${ }^{1,6,10}$.

Depression is a disease of different etiologies, characterized by severe clinical manifestations and significant behavior alterations. When it is not adequately diagnosed and treated it results in important distress to the individual, rendering him incapable of work, social and family life ${ }^{13}$. A population study carried out by WHO on the global depression map develop through OMS and covering 18 countries, found that, for most of the cases, the age of symptom onset was between 24 and 25 years and prevalence among women was twice as high as in men ${ }^{14}$. The rates of humor alterations in the general population indicate prevalence between $15.1 \%$ and $16.8 \%$, and in São Paulo 18.5\% ${ }^{15}$. Projections indicate that in 2020 it will reach 2 nd place among the diseases that will most affect developed countries and $1^{\text {st }}$ place in developing countries ${ }^{16}$.

Anxiety is a feeling of apprehension, disquietude and discomfort when facing expectations of a future threat, accompanied by somatic signs indicative of nervous system alterations ${ }^{17}$. It is considered pathological when very intense or out of proportion to the stimulus, significantly affecting the quality of life of the patient ${ }^{18}$. Anxiety disorders are among the most frequent symptom complexes in psychiatry. The first symptoms are manifested in young people, at the end of adolescence and early adulthood. It is 2 to 3 times more common in female students ${ }^{17}$.

In Brazil, the Psychiatric Morbidity Multicentric Study found index from $8 \%$ to $18 \%$ of anxiety and phobia ${ }^{19}$. The Catchment Area Study, SP-ECA, the Psychiatry Institute of USP Clinical Hospital, performed with 1,464 people, found the index of $16.8 \%$ for anxiety disorders. Except for chemical dependency, women had higher risk prevalence for any non-psychotic mental disorder, and these results are in agreement with the literature ${ }^{15}$.

Research seeking associations between psychiatric disorders (especially depression and anxiety) and use of drugs are frequent. Studies demonstrate significant association between the presence of such disorders and use of psychoactive substances, indicating that these individuals present higher risk for drug abuse ${ }^{19}$. The use of drugs facilitates the onset of depression; on the other hand, previous depression is an important factor for the use of drugs ${ }^{20}$.

Upon entering the school of Medicine, the student begins undergoing changes, both in personal and social life; he faces a new reality and has to respond to this situation, which may be adapted or not. The lack of adaptation creates situations of conflict that may trigger emotional disorders, with prevalence of depression and anxiety ${ }^{1,710,21}$.

Some scholars begin the course without the exact notion of what a medical career is and at a time of emotional immaturity. The choice of professional identity is sometimes before their own identity as a person. Self-knowledge is important to enable greater emotional balance in the performance of their activities ${ }^{21}$.

Psychological phases experienced by the student during the formative years stand out ${ }^{1,21}$ : 
1) Phase of Euphoria: a moment of great idealization, full of expectations and intense emotional load. The school of medicine is seen by the student as an idealized continent, where there will be no anguish and insecurity but only achievements ${ }^{1,21}$.

2) Phase of Disillusionment: The student gets in touch with the content of the course, the staggering volume of studies, the difficulties of different subjects, the demands of academic training and its inherent challenges ${ }^{1,21}$.

3) Internship Phase: Medical practice begins. The student will have before him a person with whom a doctor-patient relationship will be established, there will be a change of role and function. The fear of making mistakes may generate feelings of anguish, insecurity and impotence ${ }^{1,6,9,12}$. The internship groups are formed, in which personal characteristics will make a difference and be tested, and the students may be accepted by the group or not $1,21,22$.

Emotional intelligence, the ability to face conflicts, will be an important factor in the way that the student will handle his own limits and, and anxieties, and how he will prepare his experiences at that moment $t^{1,21,22}$

The emotional experiences, the way he deals with his own limits and anguish, will determine how he will process the experiences of this period ${ }^{1,7,22}$. Aspects of academic training such as excessive pressure, high level of demand imposed on self and on society, overload of subjects, little time for leisure, competitiveness among colleagues, contact with the patient and with death $5,6,23,24$, an idealized image of the physician and the medical student are identified as factors that are detrimental to physical and mental health $13,6,11$. However, personality traits, life experience and psychiatric morbidity in the family are etiologic factors considered more important than occupational factors in the determination of vulnerability to stress ${ }^{22,25,26}$. Factors that are inherent to the teaching process may negatively influence the mental health of some students, which will be reflected in his academic performance and his behavior by means of inadequate postures, affecting the manner he will deal with the profession and establish the doctor-patient relationship ${ }^{6,10,22,26}$.

The objective of the present study was to ascertain the prevalence of depressive and anxiety symptoms in medical students at the Centro Universitário Lusíada (Unilus) during 2012 and evaluate if there is correlation between the onset of symptoms and the year the student is enrolled in.

\section{METHODS}

A descriptive cross-sectional study with students enrolled in the course of Medicine at Unilus, from the $1^{\text {st }}$ to the 6 th year, in 2012.
The students were oriented about the objectives of the research, its voluntary character and the confidentiality of information, whose results would be demonstrated globally, without individual identification. Those who agreed to participate signed the Term of Free and Informed Consent (TFIC); after these were handed in, they answered the questionnaires. Their application was done by only one investigator, in the classrooms of the $1^{\text {st }}, 2^{\text {nd }}, 3^{\text {rd }}$ and $4^{\text {th }}$ years (campus II) and at the teaching hospital (Hospital Guilherme Álvaro) to students of the $5^{\text {th }}$ and $6^{\text {th }}$ years, either before or after academic activities, with the agreement and cooperation of the respective professors. The average time for application of the instruments was 30 minutes for each student.

The measurement instruments used were:

1) Questionnaire of socioeconomic-demographic characteristics with the following information: age, sex, marital status, children, city of origin, type of residence, religion, leisure, use of drugs, psychological or psychiatric treatment, professional choice, family income.

2) Beck Depression Inventory (BDI): self-applicable instrument, used to assess depressive symptoms and attitudes. Composed of 21 items, with increasing degrees of intensity of symptoms and scores from 0 to 3 . Validated in Brazil by Gorenstein and Andrade ${ }^{27}$. In this study were used the cut-off scores recommended by the Center for Cognitive Therapy: 0 to 10 (absent or minimal), 10 to 18 (mild), 19 to 29 (moderate) and above 30 (severe).

3) Beck Anxiety Inventory (BAI): self-applicable instrument, that measures the intensity of symptoms and attitudes denoting anxiety. Adapted and validated in the Portuguese version by Cunha ${ }^{28}$. Composed of 21 items, with increasing levels of severity, from 0 to 3 points. The Brazilian criteria defined by Cunha were adopted for classification of symptoms - 0 to 10 (absent or minimal), 11 to 19 (mild), 20 to 30 (moderate) and 31 to 63 (severe).

After collecting data from previously completed form, used the Excel Microsoft ${ }^{\circ}$ program, Version 2010, to place the data and subsequent analysis with Statistical Package statistical package for Social Sciences (SPSS version 18 for Windows).

It was first performed descriptive statistics for all variables of interest in the study. Qualitative variables were presented as absolute and relative values. Quantitative variables were expressed through their central tendency and dispersion. In referring to the statistical analytical quantitative variables were initially tested to determine whether they were normally distributed based on the absolute values of the maximum difference between the observed and the expected cumulative distribution cumulative distribution, assuming the 
assumption of normality by the tests Kolmogorov-Smirnov (with Lilliefors correction) and Shapiro-Wilk. All samples in this study did not meet the normal criteria and were treated as non-parametric and was used chi-square test for extensive tables and Fisher's exact test when necessary. We considered the significance level of $5 \%$.

Approved by the Research Ethics Committee for Human Beings of Unilus protocol number 135/2012.

\section{RESULTS}

Of the 671 students enrolled, 657 (97.91\%) participated in the study; the mean age was 22.7 years, 402 (61.2\%) were women and 255 (38.8\%) men, and only 11 (1.7\%) were married. As regards religion, 422 (64.2\%) are Catholic, 47 (7.2\%) protestants, 98 (14.9\%) spiritualists, 54 (8.2\%) atheists, 36 (5.5\%) are from other religions. They live with colleagues (44.7\%), alone (28.9\%) or with their families (24.6\%). Concerning the city of origin, $268(40.7 \%)$ are from the city of S. Paulo, 235 (35.7\%) from other cities in the state of São Paulo, 112 (17.0\%) are from Baixada Santista, 41 (6.2\%) are from other states and $1(0.15 \%)$ is from another country (Table 1$)$.

Table 1. Students socioeconomic-demographic characteristics

\begin{tabular}{lcl}
\hline & & $\mathrm{N}=657(\%)$ \\
\hline Mean age & Average & 22.7 years \\
Gender & Men's & $255(38.8)$ \\
& Female & $402(61.2)$
\end{tabular}

Marital status

\begin{tabular}{lcc} 
& Single without boyfriend & $341(51.9)$ \\
Single with boyfriend & $301(45.8)$ \\
Stable married or union & $11(1.7)$ \\
Other & $4(0.6)$ \\
Religion & Catholic & $422(64.2)$ \\
Evangelical & $47(7.2)$ \\
Spiritualist & $98(14.9)$ \\
Atheist & $54(8.2)$ \\
Other & $36(5.5)$ \\
Bity of origin & $112(17.0)$ \\
Baixada Santista & $268(40.7)$ \\
São Paulo & $235(35.7)$ \\
Other city (SP) & $41(6.2)$ \\
Other states & $1(0.15)$ \\
Other country & \\
Family & $162(24.6)$ \\
Alone & $190(28.9)$ \\
Friends & $294(44.7)$ \\
\hline
\end{tabular}

As to leisure activities, participants could mark more than one option; the Internet was mentioned by 500 (76.1\%) students, followed by movies, mentioned by 415 (63.1\%) and social gatherings, also by $415(63,1 \%)$, sport activities by $377(57.3 \%)$, reading by 246 (37.4\%), "other activity" by 114 (17.3\%) and 4 (0.6\%) did not mention any leisure activity.

Among all of the students, 106 (16.1\%) do not drink alcoholic beverages and 551 (83.9\%) do. Of those who answered yes, 147 (22.4\%) rarely drink, 292 (44.4\%) drink on weekends, 74 (11.3\%) do it frequently and 38 students did not answer. Most of them, 627 (95.4\%) do not smoke cigarettes and only 30 (4.6\%) do. As regards illicit drugs, 603 (91.8\%) informed that they do not use them and 54 (8.2\%) answered affirmatively.

A total of 570 (86.8\%) students informed they have never undergone psychiatric treatment, while 87 (13.3\%) already have; 464 (70.6\%) believe they should not have the treatment and 58 (8.8\%) that they should; 135 (20\%) did not answer. Concerning psychological therapy, 447 (68.0\%) have never had it, 206 (31.4\%) have, 303 (46.1\%) indicated they should not have it and 193 (29.4\%) that they should have it, while 161 (24\%) did not answer. The great majority, 636 (96.8\%) informed they were happy with their professional choice. Only $29(4.4 \%)$ students were engaged in some kind of labor activity. As to family income, 376 (57.2\%) students were in the range of 20 minimum salaries or more, 167 (25.4\%) were in the range between 10 and 20 salaries, 74 (11.3\%) between 4 and 10 salaries, 22 (3.3\%) between 2 and 4 salaries, 14 (2.1\%) up to 2 minimum salaries and 4 (0.6\%) did not answer.

\section{DISCUSSION}

\section{Depression}

Studies in scientific literature confirm that, in several parts of the world, medical students show higher rates of depressive and anxiety symptoms compared to the general population, possibly related to factors that are inherent to the academic process $1,2,4,5,7-11,22,23,2,2,29-34$.

In this investigation with the students of the course of Medicine at the Centro Universitário Lusíada, the prevalence of depressive symptoms was 30\% (Table 2). Comparing the data obtained in this study with others carried out with the same instrument (BDI), slightly higher scores were observed than those found by Macedo et al. $(23.1 \%)^{33}$ (Santos/SP, 2007, $n=290-1^{\text {st }}$ to $4^{\text {th }}$ year), however, there was percentage agreement with the results found by Ahmed et al. $(28.6 \%)^{4}$ (Dubai, 2009, $\mathrm{n}=165)$, Bruch et al. (28.4\%) ${ }^{24}$ (Tubarão/SC, 2009, $n=233)$, Amaral et al. $(26.8 \%)^{9}$ (Goiânia/GO, 2008, $n$ = 287), below those cited by Alvi et al. $(35.1 \%)^{32}$ (Paquistão, 2010, $n=278)$, Baldassin et al. $(38.2 \%)^{31}(A B C / S P, 2008, n=$ 481), Souza (39\%)"11 (Curitiba/PR, 2010, $n=359)$, Porcu et al. $(49.2 \%)^{23}$ (Maringá/PR, 2001, $\left.n=126\right)$, and much lower than 
the indexes obtained in the studies of Leal et al. (70\%) (Belém/PA, 2010, $n=155$ ) and Abrão et al. $(79 \%)^{5}$ (Uberlândia/ $M G, 2004, n=400$ ). Although the two last studies used the same instrument, they followed different cut-off parameters, more rigorous, (0-3/4-7/8-15/15-16) which probably justifies the higher symptom prevalence rates Leão Pereira (S. Paulo/ $S P, 2010, n=155)^{34}$ in a study with only $6^{\text {th }}$ year students $=$ $20 \%$ of depressive symptoms, this study $6^{\text {th }}$ year $=18.8 \%$.

In this study the score indexes obtained in the $1^{\text {st }}$ year, as they were the lowest, became reference parameters for the other years of the course. In the comparison among the years, a statistically significant correlation was found for depressive symptoms among students in the $2^{\text {nd }}, 3^{\text {rd }}, 4^{\text {th }}$ and $5^{\text {th }}$ years. There was no significance in the 6 th year (Table 3 - Figure 1).

Table 2. Distribution of the total and percentage of students according to scores obtained in the BDI (Beck Depression Inventory) to grade depressive symptoms

\begin{tabular}{lcc}
\hline & No. & $\%$ \\
\hline No symptoms & 457 & 69.6 \\
Mild & 155 & 23.5 \\
Moderate & 38 & 5.8 \\
Severe & 7 & 1.1 \\
Total & 657 & 100.0 \\
\hline
\end{tabular}

Table 3. Distribution of the total and percentage, "Odds Ratio" and Confidence Interval of $95 \%$ of the students according to scores obtained in the BDI (Beck Depression Inventory) in the different years of the course

\begin{tabular}{lcccc}
\hline YEAR & YES & N0 & OR & CI (95\%) \\
\hline 1st & N (\%) & N (\%) & & - \\
2nd & $15(17.2)$ & $72(82.8)$ & - & - \\
3rd & $26(35.6)$ & $47(64.4)$ & 2.6 & $(1.2-5.5)$ \\
4th & $47(32.6)$ & $97(67.4)$ & 2.3 & $(1.2-4.4)$ \\
5th & $58(34.9)$ & $108(65.1)$ & 2.5 & $(1.3-4.8)$ \\
6th & $35(40.7)$ & $51(59.3)$ & 3.2 & $(1.6-6.6)$ \\
\hline
\end{tabular}

BDI

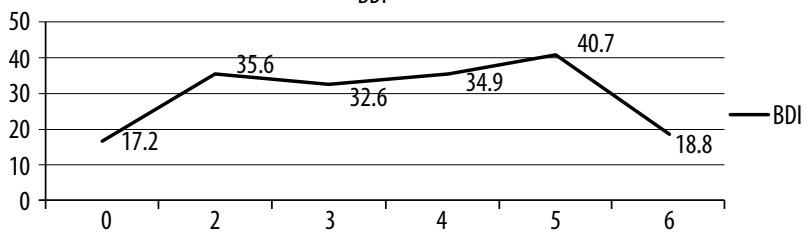

Figure 1. Percentage of depressive symptoms for the total number of students according to scores obtained in the $\mathrm{BDI}$ (Beck Depression Inventory) in the different years of the course.
When the scores obtained in the BDI are observed for the different years of the course, there is agreement among the several studies in which the lower scores are found in the $1^{\text {st }}$ year, indexes easily understood when it is considered that the student is experiencing a moment filled with fulfillment and achievements ${ }^{1,6,21}$.

When scores are stratified by year of the course, a marked increase is seen in the scores from the $1^{\text {st }}(17.2 \%)$ to the $2^{\text {nd }}$ year (35.6\%). Such figures agree with studies that point out to increase in scores obtained from the $1^{\text {st }}$ to the $2^{\text {nd }}$ or $3^{\text {rd }}$ year ${ }^{4,5,23,33}$. These results may be explained considering the progression of the own student ${ }^{5}$ : after an initial period of euphoria, follows the "phase of disillusionment", when the demands of academic training and the difficulties inherent to it stand out. At this time the student perceives that achieving the so ardently desired place in the course of Medicine has a price and now he will have less availability for family and social activities ${ }^{1,21}$.

Later on there was a slight decline in the depression rate from the $2^{\text {nd }}$ year $(35.6 \%)$ to the $3^{\text {rd }}$ year $(32.6 \%)$, which remained relatively stable in the $4^{\text {th }}$ year $(34.9 \%)$, suggesting a possible adaptation to the teaching method and the course dynamics' ${ }^{1}$. From the $4^{\text {th }}(34.9 \%)$ to the $5^{\text {th }}$ year $(40.7 \%)$ there was a new increase, the scores found in this year being the highest among the other years of the course. These results are probably associated with alterations that take place in this phase, when the medical student, already at the teaching hospital, begins to have closer contact with the patients and there is a transition from the academic to the professional model. It is also in the $5^{\text {th }}$ year that the internship period begins and with it the difficult task of forming groups, when, more that the academic performance, the personal characteristics will be tested and the students may be accepted by their colleagues or not ${ }^{1,21}$. At this institution, it is a known fact that situations of conflict among the students have occurred, when by their own personality characteristics they found it difficult to establish bonds that would reflect in relationships with colleagues, who were directly or indirectly excluded from the other groups, generating feelings of rejection and abandonment. Another aspect that may be related to the recrudescence of symptoms is the psychological stress presented by some students when they have to deal with the pain and the suffering of another human being ${ }^{6}$. Some of them live this phase intensely and with much distress, with negative effects on their well-being ${ }^{10,22,34}$.

In the $6^{\text {th }}$ year there was decrease in scores of depressive symptoms (18.8\%); these results disagreed with the literature, which showed studies pointing to higher rates in the last year of the course $\mathrm{e}^{11,23,31}$ associated with a period with a heavy load of study, duty schedules, high competitiveness with preparation for the residency exam and doubts regarding the specialty, many times hindering the personal and social life of the student ${ }^{1,10,22,31,34}$. In this educational institution 
(Unilus), the medical school structure on the $6^{\text {th }}$ year is similar to the $5^{\text {th }}$ year; thus, it is believed that the difference found in this study in relation to the literature, it is because the student already faces the difficulties on the $5^{\text {th }}$ year, and the rates found at this time of course were the highest, which probably justifies lower scores for depressive symptoms in the $6^{\text {th }}$ year.

On the other hand, through the socioeconomic-demographic questionnaire it was ascertained that the percentage of female students is higher than the percentage of male students at this institution, around $60 \%$ and $40 \%$, respectively. Comparing the scores obtained in the $\mathrm{BDI}$ between these two groups, it was found that there is predominance of depressive symptoms among women in each year of the course and in the total number of students (Figure 2). This difference was statistically significant particularly in the $4^{\text {th }}$ year, indicating that female students are more vulnerable to the onset of depressive symptoms compared to men. These results agree with those found in the literature, both for the general ${ }^{19}$ and the specific populations ${ }^{2,5,8,9,11,31,33-35}$.

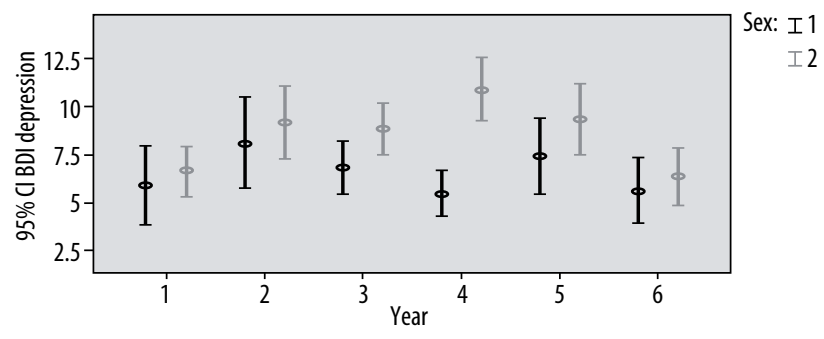

Figure 2. Distribution of scores obtained in the BDI of total students according to the gender.

\section{Anxiety}

As regards anxiety, a smaller number of articles was found in scientific literature, sometimes carried out with different instruments, which makes it more difficult to compare results. This study found a $21.5 \%$ prevalence of anxiety symptoms (Table 4). Comparing the results with other studies carried out with the same instrument (BAl), Ahmed et al. $(28.7 \%)^{4}$ (Dubai, 2009, $\mathrm{n}=165$ ) and Alvi et al. $(47.7 \%)^{32}$ (Paquistão, $2010, n=279$ ) while Leão Pereira obtained results three ti-

Table 4. Distribution of the total and percentage of students according to scores obtained in the BAI (Beck Anxiety Inventory) to grade anxiety symptoms

\begin{tabular}{lcc}
\hline & No. & $\%$ \\
\hline No symptoms & 516 & 78.5 \\
Mild & 104 & 15.8 \\
Moderate & 29 & 4.4 \\
Severe & 8 & 1.2 \\
Total & 657 & 100.0 \\
\hline
\end{tabular}

mes higher (27\% - only with $6^{\text {th }}$ year students) ${ }^{34}$ (São Paulo/ SP, 2010, $n=155)$ than this study (9.9\%). With different instruments Baldassin et al. (ABC/SP, 2001, $\mathrm{n}=481)^{36}$ Bruch et al. (Tubarão/SC, 2009, $\mathrm{n}=233)^{24}$ and Souza (Curitiba/PR, 2010, $\mathrm{n}=359)^{11}$ obtained high rates for symptoms anxious. Note that the comparison is questionable due to use of different measurement instruments.

When BAI results were stratified per year of the course, considering the $6^{\text {th }}$ year as reference (lowest scores: $9.9 \%$ ), the rates found in the $1^{\text {st }}$ year (18.4\%) were not statistically significant. As was found for depressive symptoms, in the $2^{\text {nd }}$ year there was also an increase in anxiety scores (28.8\%), in agreement with other studies ${ }^{4,11,36}$, followed by a decrease that remained basically the same in the $3^{\text {rd }}(22.2 \%)$ and $4^{\text {th }}$ years (22.9\%). A slight elevation was found during the $5^{\text {th }}$ year (27.9\%) (Table 5 - Figure 3). The increase in prevalence rates for anxiety symptoms may be understood considering the same stressful factors experienced by students presenting depressive symptoms.

Studies identify the last year of the course of Medicine as a moment of crisis with a high degree of stress, worsening of the quality of life and, therefore, higher prevalence of symp-

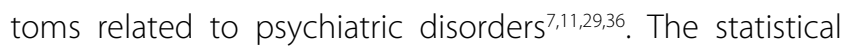
results obtained in this work detected a marked diminution of symptoms in the $6^{\text {th }}$ year $(9.9 \%)$ in comparison with the previous years, and consequently did not confirm the data in the literature (Table 5 - Figure 3).

Table 5. Distribution of the total and percentage, "Odds Ratio" and Confidence Interval of $95 \%$ of the students according to scores obtained in the BAI (Beck Anxiety Inventory) in the different years of the course

\begin{tabular}{lcccc}
\hline Year & $\begin{array}{c}\text { Yes } \\
\mathbf{N}(\%)\end{array}$ & $\begin{array}{c}\mathrm{No} \\
\mathbf{N}(\%)\end{array}$ & Or & $\mathrm{CI}(95 \%)$ \\
\hline 1st & $16(18.4)$ & $71(81.6)$ & 2.05 & $(0.87-4.7)$ \\
2nd & $21(28.8)$ & $52(71.2)$ & 3.6 & $(1.6-8.3)$ \\
3rd & $32(22.2)$ & $112(77.8)$ & 2.6 & $(1.2-5.5)$ \\
4th & $38(22.9)$ & $128(77.1)$ & 2.7 & $(1.2-5.7)$ \\
5th & $24(27.9)$ & $62(72.1)$ & 3.5 & $(1.5-7.8)$ \\
6th & $10(9.9)$ & $91(90.1)$ & - & - \\
\hline
\end{tabular}

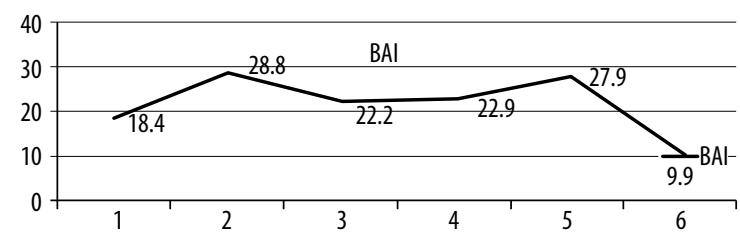

Figure 3. Percentage of anxiety symptoms for the total number of students according to scores obtained in the BAI (Beck Anxiety Inventory) in the different years of the course. 
As stated above, we believe that once you are on the $6^{\text {th }}$ year, the student has already gone through the adaptation process on the $5^{\text {th }}$ year. In this teaching Institution (Unilus), the structure of the course of Medicine in the 6 th year is similar to that of the $5^{\text {th }}$ year, which probably justifies the adaptation of the students in the final phase.

Seeking to better understand these issues, it is our belief that one of the hypotheses is that at this moment the student is overcoming difficulties and managing to adequately deal with his own limits, experiencing specific situations of the end of the course as a development process of emotional maturity and growth ${ }^{34}$. Another hypothesis, of greater concern, is that in face of high rates of depressive and anxiety symptoms, associated with limitations imposed by an intensive load of study and training, the student is developing mechanisms of compensation, dealing with difficulties by means of inadequate strategies, which oftentimes may signify clinical expressions of psychological stress $3,34,37$.

As regards gender, higher symptom scores were found among the female students in every year of the course and in the global result, especially in the $4^{\text {th }}$ year when a statistically significant difference was detected between men and women, indicating that the female sex presents a considerably higher risk for anxiety in relation to the male (Figure 4). These findings agree with the general ${ }^{15}$ and specific literature, in which other studies confirm greater vulnerability of female gender to disorders of this nature $8,11,31,32$. These data are particularly significant when it is considered that, in the last few years, there was an important escalation in the number of women in medical schools, and that in many of them, such as in this institution, where this work was carried out, they constitute the majority of students. In face of several studies, rectifying that there is prevalence of depressive and anxiety symptoms in the female gender, it is questioned which would be the specific characteristics of women that would justify these rates. Seeking to answer these questions, it is concluded that female students present different reactions in stressful situations, are more sensitive and therefore more affected by the feelings of the patients; on the other hand, these characteristics afford to the female gender a greater capacity for empathy ${ }^{11}$.

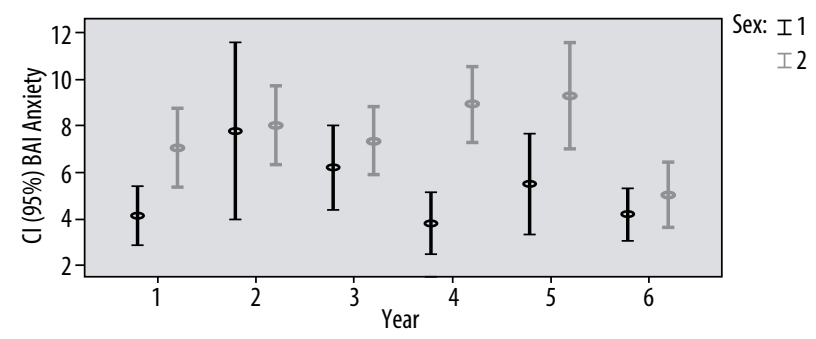

Figure 4. Distribution of scores obtained in the BAI of total students according to the gender.
Another aspect that should be observed is the correlation between psychiatric disorders and the use of drugs. Studies confirm that individuals that present these symptom complexes are at a higher risk for abuse of licit and illicit substances ${ }^{15}$. The use of drugs may trigger depression; in addition, previous depression is an important factor for drug use $\mathrm{e}^{20}$. Bearing in mind that the population of this research is eminently young and that it is in this period that the first emotional disorder symptoms are manifested, these students are considered more vulnerable to behaviors associated with risks, mainly the use of drugs ${ }^{38}$. The Questionnaire of socioeconomic-demographic characteristics found that $83.9 \%$ of the students affirmed that they used alcohol and 8.2\% that they used illicit drugs. This study did not have as main objective to approach this issue, but we considered this situation a reason for concern. Studies indicate that there is a worldwide tendency to increased use of drugs, particularly in the university atmosphere ${ }^{39}$ and that students of Medicine feel less vulnerable to the harm done by such substances ${ }^{40}$. In this manner we believe

Depressive and anxiety symptoms in medical students that the theme deserves to be investigated in future studies, for possible preventive measures to these risk factors.

Finally, another issue to be considered is suicide. Research points out that $95 \%$ of the persons that commit suicide are diagnosed with psychiatric disorders and that the main significant factors for suicidal thoughts are anxiety and depression ${ }^{26,30}$. It is important to emphasize that the risk exists and should be regarded with the gravity it deserves.

\section{CONCLUSION}

The high prevalence of depressive and anxiety symptoms in medical students is possibly connected with stressful factors inherent to academic training, associated with psychodynamic characteristics. Some of the students, as a consequence of their own personality traits, demonstrate more acute emotional distress and greater difficulties to face conflictive issues, becoming more vulnerable to emotional disorders and consequently to risk situations. Issues attributed to the medical career may, in truth, be related to experiences preceding the university period. In this context are involved intrinsic and extrinsic aspects, that may influence the performance of the student, affecting his personal, family and professional life.

Work carried out at Centro Universitário Lusíada - UNILUS - Santos/SP.

\section{INDIVIDUAL CONTRIBUTIONS}

Rosana Denobile Serra - Data collection and writing. 
Sandra Lopes Mattos e Dinato - Choice of subject and writing.

Marcos Montani Caseiro - Statistical study.

\section{CONFLICTS OF INTEREST}

The authors Rosana Denobile Serra, Sandra Lopes Mattos e Dinato and Marcos Montani Caseiro not present conflicts of interest.

\section{ACKNOWLEDGEMENTS}

We thank all those who, directly or indirectly, have contributed to make this research possible, particularly Nelson Teixeira, President of UNILUS, who authorized it.

\section{REFERENCES}

1. Millan LR, De Marco OLN, Rossi E, Millan MPB, Arruda PCV. Alguns aspectos psicológicos ligados à formação médica. In: Millan LR, De Marco OLN, Rossi E, Arruda PCV. 0 universo psicológico do futuro médico: vocação, vicissitudes e perspectivas. São Paulo: Casa do Psicólogo; 1999.

2. Dyrbye LN, Thomas MR, Shanafelt TD. Systematic review of depression, anxiety, and other indicators of psychological distress among U.S. and Canadian medical students. Acad Med. 2006;81(4):354-73.

3. Baldassin S. Ansiedade e depressão no estudante de medicina: revisão de estudos brasileiros. Rev Bras Educ Med. 2010;6:19-26.

4. Ahmed I, Banu H, Al-FageerR, Al-Suwaidi R. Cognitive emotions: depression and anxiety in medical students and staff. J Crit Care. 2009;24(3):1-7.

5. Abrão CB, Coelho EP, Passos LBS. Prevalência de sintomas depressivos entre estudantes de medicina da Universidade Federal de Uberlândia. Rev Bras Educ Med. 2008;32(3):315-23.

6. Quintana AM, Rodrigues AT, Arpini DM, Bassi LA, Cecim PS, Santos MS. A angústia na formação do estudante de medicina. Rev Bras Educ Med. 2008;32(1):7-14.

7. Lima MCP, Domingues MS, Cerqueira ATAR. Prevalência e fatores de risco para transtornos mentais comuns entre estudantes de medicina. Rev Saude Publica. 2006;40(6):1035-41.

8. Leal RA, Santos ALM, Celyne AS, Borges RGL, Barbosa ANO. Depressão e traços de ansiedade em estudantes de medicina. Rev Para Med. 2010;24(2): 13-21.

9. Amaral GF, Gomide LMP, Batista MP, Piccolo PP, Teles TBG, Oliveira PM, et al. Sintomas depressivos em acadêmicos de medicina da Universidade Federal de Goiás: um estudo de prevalência. Rev Psiquiatr Rio Gd Sul. 2008;30(2):124-30.

10. Gonçalves MB, Benevides-Pereira AMT. Considerações sobre 0 ensino médico no Brasil: consequências afetivo-emocionais nos estudantes. Rev Bras Educ Med. 2009;33(3):482-93.

11. Souza L. Prevalência de sintomas depressivos, ansiosos e estresse em acadêmicos de medicina. 2010. Disponível em: <http://www.teses.usp.br/teses/disponiveis/5/5131/tde01022011-181552/publico/LucianoSouza.pdf>. Acessado em: 8 set. 2012.

12. Definição de inteligência emocional. Disponível em: <https://psicointem.wordpress.com/ definicao-de-inteligencia-emocional >. Acessado em: nov. 2012.

13. Moreno DH, Moreno RA, Soeiro-de-Souza MG. Transtorno depressivo ao longo da vida. In: Fortenza OV, Miguel EC. Compêndio de psiquiatria clínica. São Paulo: Manole; 2012.

14. Bromet E, Andrade LH, Hwang I, Sampson NA, Alonso J, Girolamo G, et al. Cross national epidemiology of DSM-IV major depressive episode. BMC Med. 2011;9:90.

15. Andrade L, Walters EE, Gentil V, Laurenti R. Prevalence of ICD-10 mental disorders in a catchment area in the city of São Paulo, Brazil. Soc Psychiatry Psychiatr Epidemiol. 2002;37(7):316-25.
16. Fleck MPA, Lafer L, Sougey EB, Del Porto JA, Brasil MA, Juruena MF. Diretrizes da Associação Médica Brasileira para o tratamento da depressão (versão integral). Rev Bras Psiquiatr. 2003;25(2):114-22

17. Bernik M, Corregiari F, Stella F, Asbhr FR. Transtornos de ansiedade ao longo da vida. In: Fortenza OV, Miguel EC. Compêndio de psiquiatria clínica. São Paulo: Manole; 2012.

18. Gentil V, Neto FL, Maciel LMA. Transtornos ansiosos. In: Lousã Neto MR, Motta T, Wang YP, Elkis H. Psiquiatria básica. Porto Alegre: Artes Médicas; 1995.

19. Almeida Filho N, Mari JJ, Coutinho E, França JF, Fernandes JG, Andreoli SB, et al. Estudo multicêntrico de morbidade psiquiátrica em áreas urbanas brasileiras. Rev ABP-APAL. 1992;14(3):93-104

20. Saide OL. Depressão e uso de drogas. Rev HUPE. 2011;10(2):47-60.

21. Valle V, Scharlau HC, Cataldo Neto A. 0 estudante de medicina. In: Cataldo Neto A, Antonello I, Lopes MHI. 0 estudante de medicina e o paciente: uma aproximação à prática médica. Porto Alegre: EdiPURCRS; 2006.

22. Nogueira-Martins LA. Saúde mental do médico e do estudante de medicina. Int J Psychiatry Med. 2006. Disponível em: <http://www.polbr.med.br/ano96/saudment.php>. Acessado em: set. 2012

23. Porcu M, Fritzen CV, Helber C. Sintomas depressivos nos estudantes de medicina da Universidade Estadual de Maringá. Psiquiatr Prat Med. 2001;34(1).

24. Bruch TP, Carneiro EA, Jornada LK. Presença de sintomas psiquiátricos em estudantes de medicina de universidade do sul do Brasil. Arq Catarin Med. 2009;38(4):61-5.

25. Vaillant GE, Sobowale NC, McArthur C. Some psychologic vulnerabilities of physicians. N Engl J Med. 1972;287(8):372-5.

26. Meleiro AMAS. Suicídio entre médicos e estudantes de medicina. Rev Assoc Med Bras.1998;44(2):135-40.

27. Gorenstein C, Andrade LHGS. Inventário de Depressão de Beck - propriedades psicométricas da versão em português. In: Gorenstein C, Andrade LHSG, Zuardi AW. Escalas de Avaliação Clínica em Psiquiatria e Psicofarmacologia. São Paulo: Lemos; 2000.

28. Cunha JA. Manual da versão em português das Escalas Beck. São Paulo: Casa do Psicólogo; 2011.

29. Rosal MC, Ockene IS, Ockene JK, Barrett SV, Ma Y, Hebert JR. A longitudinal study of students' depression at one medical school. Acad Med. 1997;72(6):542-6.

30. Tyssen R, Vaglum P, Grønvold NT, Ekeberg 0 . Suicidal ideation among medical students and young physicians: a nationwide and prospective study of prevalence and predictors. J Affect Disord. 2001;64(1):69-79.

31. Baldassin S, Alves TC, de Andrade AG, Nogueira-Martins LA. The characteristics of depressive symptoms in medical students during medical education and training: a crosssectional study. BMC Med Educ. 2008;8:60.

32. Alvi T, Assad F, Ramzan M, Khan FA. Depression, anxiety and their associated factors among medical students. J Coll Physicians Surg Pak. 2010;20(2):122-6.

33. Macedo PNAG, Nardotto LL, Deickmann LHJ, Ferreira YD, Macedo BAG, Santos MAP, et al. Fatores associados a sintomas depressivos entre estudantes de medicina da UNILUS. Rev Bras Educ Med. 2009;33(4):595-604.

34. Leão Pereira PBOS. Bem-estar e busca de ajuda: um estudo junto aos alunos de medicina ao final do curso. 2010. Disponível em: < www.teses.usp.br/teses/../5/.../PaulaBertozzi0liveiraSouzaLeaoPereira.pdf >. Acessado em: set. 2012.

35. Schwenk TL, Davis $L$, Wimsatt LA. Depression, stigma, and suicidal ideation in medical students. JAMA. 2010;304(11):1181-90.

36. Baldassin SP, Martins LC, Andrade AG. Traços de ansiedade entre estudantes de medicina. Arq Med ABC. 2006;31(1):27-31.

37. Benevides-Pereira AMT, Gonçalves MB. Transtornos emocionais e a formação em Medicina: um estudo longitudinal. Rev Bras Educ Med. 2009;33(1):10-23.

38. Wagner GA, Andrade AG. Uso de álcool, tabaco e outras drogas entre estudantes universitários brasileiros. Rev Psiquiatr Clin. 2008;35(Suppl 1):48-54

39. Stempliuk VA, Barroso LP, Andrade AG, Nicastri S, Malbergier A. Estudo comparativo entre 1996 e 2001 do uso de drogas por alunos da graduação da Universidade de São Paulo. Rev Bras Psiquiatr. 2005;27(3):185-93.

40. Mesquita EM, Nunes AJ, Cohen C. Avaliação das atitudes dos estudantes de medicina frente ao abuso de drogas por colegas do meio acadêmico. Rev Psiquiatr Clin. 2008;35(Suppl 1):8-12. 